5. Висновок Конституційного Суду України від 14 березня 2001 р. № 1-в/2001. URL: https://zakon.rada.gov.ua/laws/show/v001v710-01.

6. Висновок Конституційного Суду України від 16 жовтня 2002 р. № 1-в/2002. URL: https://zakon.rada.gov.ua/laws/show/v001v710-02.

7. Висновок Конституційного Суду України від 30 жовтня 2003 р. № 1-в/2003. URL: http://zakon.rada.gov.ua/laws/show/v001v710-03.

8. Висновок Конституційного Суду України від 05 листопада 2003 р. № 2-в/2003. URL: https://zakon.rada.gov.ua/laws/show/v002v710-03.

9. Висновок Конституційного Суду України від 10 грудня 2003 р. № 3-в/2003. URL: http://zakon.rada.gov.ua/laws/show/v003v710-03.

10. Висновок Конституційного Суду України від 16 березня 2004 р. № 1-в/2004. URL: https://zakon.rada.gov.ua/laws/show/v001v710-04.

11. Висновок Конституційного Суду України від 15 січня 2008 р. № 1-в/2008. URL: https://zakon.rada.gov.ua/laws/show/ru/v001v710-08.

12.Висновок Конституційного Суду України від 01 квітня 2010 р. № 1-в/2010. URL: http://zakon.rada.gov.ua/laws/show/v001v710-10.

13.Висновок Конституційного Суду України від 17 червня 2010 р. № 2-в/2010. URL: https://zakon.rada.gov.ua/laws/show/v002v710-10

14.Висновок Конституційного Суду України від 10 липня 2012 р. № 1-в/2012. URL: http://zakon.rada.gov.ua/laws/show/v001v710-12.

15.Висновок Конституційного Суду України від 16 червня 2015 р. № 1-в/2015. URL: https://zakon.rada.gov.ua/laws/show/v001v710-15.

ГОцУЛЯк Ю. В., кандидат юридичних наук, доцент кафедри теорії та історії держави і права та адміністративного права (Донецький національний університет імені Василя Стуса)

DOI https://doi.org/10.32842/2078-3736-2019-6-1-3

\title{
ІСТОРИКО-НАЦІОНАЛЬНІ ОСНОВИ ПРАВОВОГО БУТТЯ У ВЧЕННІ Ф. К. ФОН САВІНЬЇ
}

Стаття присвячена розкриттю категорії правового буття у доктрині історичної школи права. У роботі обгрунтовується, що історична школа наголошує на обов'язковості часового виміру у праві. Право у часі не просто $\epsilon$, воно змінюється, а отже, час $є$ головним чинником його генезису. Автор доводить, що правове буття розкривається через розуміння, пізнання, засвоєння правових явищ, а не через його творення. Право це той параметр, що уже заданий буттям. Правова діяльність людини й істинний зміст права цілком можуть і не пересікатись, адже правова істина може суб'єктом і не розкритись або підмінити іiі зміст.

У статті аналізується позиція історичної школи, що правове буття розгортається не перспективно, а ретроспективно, воно уже розгорнуте, лиш потребує розумових вольових зусиль суб'єкта по збереженню його змісту. Для історичної школи права істині витоки всього правового можуть бути лише у націо-

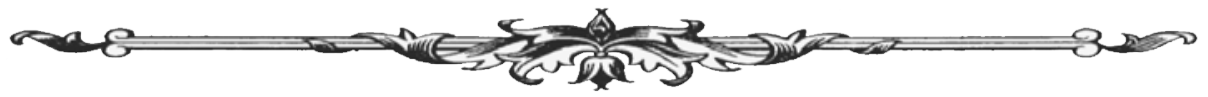


нальних локаціях. Нація дає правову матерію, без якої немає правового буття. Правова діяльність людини полягає не у створенні нових норм, а в узгодженні ï із правилами народного духу. У роботі досліджується положення, що право й окремий, відірваний від співіснування індивід несумісні, тому воно походить зі співбуття людей, а наші внутрішні афекти - це питання психологічні. Співіснування виробляє стійкіші нормативи, ніж окрема сингулярність, тому кількісно на них завжди більше людей погодяться, оскільки мають більш вдалий «спільний знаменник» взаємних зобов'язань. Із аналізу поглядів Савіньї випливає генетично-правове положення: як тільки соціальна спільнота отримує свою організацію, як тільки між людьми виникають особливого складу зв'язки, одразу ж з'являється право не як продукт творчості, а як необхідність, що забезпечує народження, існування та збереження соціальної системи. Право хоч і результат творчості народного духу, втім воно як і сам народ прив'язане до організаційного начала, що втілене у державі. Без держави впорядкувальний атрибут не просто у початковому стані, він немислимий взагалі.

Ключові слова: право, історична школа права, Савіньї, правове буття.

The article explores the disclosure of the category of legal existence in the doctrine of the historical law school. The paper argues that the law school emphasizes the obligation of time dimension in law. The law does not simply exist in time, it changes, and therefore time is the main factor nits genesis. The author argues that legal being is revealed through understanding, cognition, assimilation of legal phenomena not through its creation. The law is the parameter already given by being. Human legal activity and the true content of the law may not overlap because legal truth may not be disclosed to the subject or substitute for its content.

The article analyzes the position of the historical school that the legal being is not developed prospectively but retrospectively it has already been expanded it only requires the intellectual will of the subject to preserve its content. The true origins of all for law school law can only be in nation allocations. The nation gives legal substance without which there is no legal existence. Legal activity of a person does not mean the creation of new norms but the harmonization of them with the rules of the national spirit. The paper examines the proposition that the law and the individual separated from the coexistence are in compatible so it comes from the cohabitation of people and our internal affect is a psychological issue. Coexistence produces mores able standards than a single singularity, so quantitatively more and more people will agree on them, as they have a more successful "common denominator" of mutual obligations. The analysis of Savigny's views implies a genetic position: as soon as the social community gets organized as soon as a special bond is formed between people the law immediately emerges, not as a product of creativity but as a necessity that ensures birth existence and preserving the social system. Although the law is the result of the creativity of the people's spirit it like the people themselves is tied to the organizational principle embodied in the state. Without a state the ordering attribute is not just in its initial state it is unthinkable at all.

Key words: law, history school of law, Savigny, legal being.

Вступ. Категорія правового буття розкриває зміст права як складову частину буття. Процеси та явища, пов'язані з певним способом співіснування, супроводжуються і певним способом впорядкування: розподілом, відплатою, свободою, підкоренням, благом тощо. У такому разі право - це ніщо інше, як впорядкувальні процеси буття людини і космосу загалом. Те, що ми традиційно називаємо правом, $є$ антропологічним виміром цих впорядкувальних процесів. Категорія правового буття у різних доктринах розкривається варіативно,

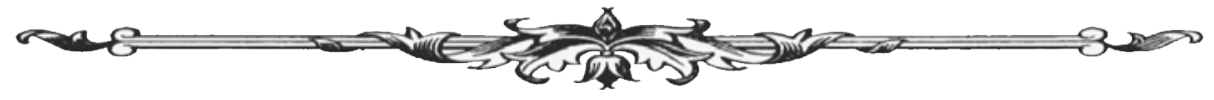


отримуючи таким чином нові змісти та інтерпретації. Впорядковуючою силою міг бути Логос, Бог, природний закон, людина, яка в свою чергу може по-різному створювати правові модуси, наприклад: індивідуально чи колективно, традиційно чи новаційно.

Постановка завдання. Традиційно-історичного та колективного варіанту витоків правового буття торкнеться наше дослідження. Ідеться про історичну школу права, яка історичний метод у праві зробила онтологічним. Отже, дана стаття буде присвячена розкриттю змістів атрибутів правового буття у праворозумінні історичної школи права.

Право як атрибут людини. «право є вихідним атрибутом людини, а за своїм розвитком - продуктом історії» [1, с. 18]. Отже, право це атрибут людини. Така позиція є опозицією до об’єктивізму в праві, який зустрічається зокрема у доктрині природного права. Ми ще з часів Гроція, Гоббса, Локка знаємо, що право розмістилося в антропологічному вимірі, втім там пошук правової істини приводив до чогось незмінного, непідвласного часу - розуму. Для історичної школи має значення не ессенція, а екзистенція права, тобто ті рушійні сили що його формують, а це - історія.

Право як космічне явище. Відомий німецький юрист ХIX ст., дослідник історичної школи права О. фон Гірке доводив, що право є абсолютно розміщеним у космосі, а саме у часі та просторі: «Право обов’язково змінюється в часі й обов'язково диференціюється в просторі» [1, с. 18]. Ключове слово у цій цитаті навіть не час і не простір, адже, зрештою, це доволі очевидні речі, що право має матеріальне зовнішнє вираження, що підтверджує його просторовість, а також діє в часі згідно класичної теорії права. Головне у цитаті - це обов'язковість часового виміру у праві, право у часі не просто є, воно змінюється, а значить, час є головним чинником його генезису.

Історична обмеженість правотворчості. Історична школа заперечує вирішальну роль людини як творця права: «Навіть найбільш великий законодавчий геній і найкращий юридичний розум не може вигадати дійсно життєздатне право, а лише може зрозуміти, що те, що робить право правом, він ніколи більше не буде вигадувати виходячи із захмарних висот рефлексії, а буде черпати це 3 глибин загальної правосвідомості» [1, с. 19]. Творчість у праві, це творчість в межах заданих правовим буттям атрибутів. Правотворчість це не вищий атрибут правового буття, це лише антропологія права. Для нас це положення має важливе онтологічне значення, а саме, що правове буття розкривається через розуміння, пізнання, засвоєння правового, а не через його творення. Право це той параметр, що уже заданий буттям, а правотворчість це розкриття його атрибутів і адаптація до суспільних відносин.

Історична школа покладає правове начало незалежно від правотворчості, правова діяльність людини і істинний зміст права цілком можуть і не пересікатись, адже правова істина може суб' єктом і не розкритись, або підмінити її зміст. Тому для Савіньї є надзвичайно важливим зберегти істинне право у часі і просторі і позбавити його влади людської волі: «Колись доречне право може віджити, закон може з самого початку розминутися з істинним змістом народного переконання, панівна влада може навіть, зловживаючи, зробити правом несправедливе» [1, с. 20]. Отже, навіть якщо людина формує надбудови, несумісні 3 правовою істиною, тим не менше вона нікуди не дівається, адже це частина нашого буття. Однією iз переваг онтологічного праворозуміння $є$ те, що воно не ділить явища на правові і не правові, навіть підміни змістів є правовими, але вони не є істинними.

Звичай як історична основа правового буття. Основою онтологічно-правового дискурсу історичної школи є те, що право у часі присутнє не фрагментарно, а постійно, неперервно: «Вона обгрунтувала початкову силу і незрівнянну цінність звичаєвого права. Вона відкрила очі на значення історичної безперервності формування права і показала, що право сучасності настільки повніше життя, наскільки воно міцніше корениться вправі минулого» [2, с. 42]. Якби право розміщувалось у часі фрагментарно, то юридичні процеси минулого мали б лише археологічне значення як пам’ять. Втім людська природа, що породила право, на думку Савіньї, назавжди вкоренила право як у просторі, так і у часі. А це означає, що витоки правового буття потрібно шукати у ланцюжку минулого, який заводить нас до зви-

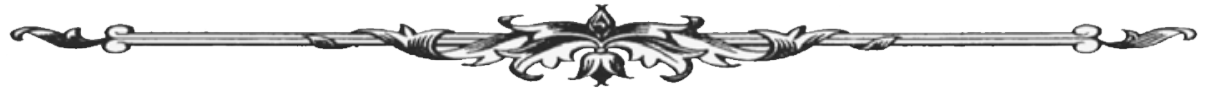


чаїв як первісної форми регулювання суспільних відносин. Ця первісність зовсім не означає примітивність, а навпаки - повноту правосвідомості та праворозуміння, адже час і розвиток суспільних відносин накладає численні семантичні нашарування на справжній зміст права, які можуть як розкривати, так і приховати правову істину. Отже, історична шкода декларує позицію, що правове буття розгортається не перспективно, а ретроспективно, воно уже розгорнуте, лиш потребує розумових вольових зусиль суб'єкта по збереженню його змісту.

Локалізачія та націоналізація правового буття. Для історичної школи права істині витоки всього правового можуть бути лише у національних локаціях, адже народний дух, як і власне сам народ це не все суспільство, а окремі його групи, окремі організми. О. фон Гірке стверджує: «У рецепції і в перевазі римського права виражався і виражається відхід від національної сутності явища, але німецьке право, як і німецький дух, не дозволили знищити себе. Супротивники звинувачували їх в німецькому націоналізмі, у нехтуванні досягненнями античної культури, в невизнанні загальнолюдського в праві» [2, с. 56]. Тепер стає зрозуміло, чому такі глобалістичні явища, як рецепція римського права, античної цивілізації відкидались історичною школою як невірні. Тому що такі правові запозичення крадуть елемент національного, і навіть якщо воно менш досконале, воно є більш живе і прийнятне для правосвідомості. Звісно, виникає логічне питання: якщо різні «народні духи» породжують істинне право, то звідки тоді береться спільність правових понять, категорій, інститутів? Іншими словами, чи може правове буття бути множиною? Нi, не може, вважаємо, що його множинність - це множинність розуміння змісту його атрибутів. Як бачимо, маємо деякі складнощі з локалізацією правових витоків, втім, поза всяким сумнівом свої національні особливості такі категорії як свобода, справедливість, благо, кара, порушення поза всяким сумнівом мають, тому що національна приналежність має вплив на розуміння особливостей екзистенції людини, колективне здійснює виховання індивідуального. Отже, атрибути правового буття отримують національне забарвлення свого змісту, а не самого буття.

Впорядкування як ключовий атрибут правового буття. Історична школа, попри постійні відсилання до витоків минулого, доходить двох важливих онтологічно-правових висновків: «У наші плоть і кров увійшло усвідомлення того, що право $є$ історичним продуктом спільного життя людей, що його розвиток і зміна - це частина процесу розвитку культури, що його стан в кожен момент часу обумовлений і визначається за допомогою постійної взаємодії між його впорядковуючою силою і силами, діючими у всіх інших функціях суспільного організму» [2, с. 46]. Отже, це співбуття та впорядкування. Буття людини це завжди співбуття із собі подібними і з природою, а співбуття завжди має відбуватись у певний спосіб, заданий правилами виховання та життя загалом. Іншими словами, співбуття і його правила уже задане ще до входження у нього конкретного індивіда, а тому не відбувається хаотично, а завжди певним чином. А це і є впорядкувальні процеси, або як вказано в цитаті впорядкувальна сила буття. Саме тому ми і констатуємо категорію правового буття, тому що впорядкувальні процеси закладені уже самим змістом космічних та антропологічних явищ.

Наиія як генератор правової матерії. Рудольф фон Ієринг відзначає ключовий компонент у творчості історичної школи: «Історична школа вважає, що матеріал права даний всім минулим нації, але не довільно (так що він випадково міг би бути таким або іншим), а породжений самим єством нації та іiї історії. Розумна ж діяльність кожної епохи має бути спрямована на перевірку цього матеріалу, даного з внутрішньою необхідністю, на його оновлення та збереження його живим» [3, с. 77]. Отже, сутність нації є основою правотворення. Важливим зауваженням $є$ те, що це не будь-який волюнтаризм, а саме діяльність, яка складає народний дух. Нація дає правову матерію, без якої немає правового буття. Таким чином правова діяльність людини полягає не у створенні нових норм, а в узгодженні їх із правилами народного духу, які варто шукати у минулому, інакше такий народ приречений на правовий «псевдос», на епоху нігілізму і декадансу, коли правове буття присутнє, але реалізоване завдяки неістинним положенням, що симулюють правильне впорядкування. Чим менше народного духу у правовій системі, тим менш живим $є$ право, правові конструкції тоді перетворюються на свого роду імпланти, які в будь-який момент можуть бути відторгнуті соціальним

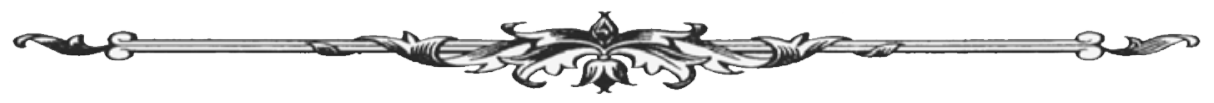


організмом. Саме тому правотворчість з позиції історичної школи - це перманентний пошук змістів народного духу, їх збереження, оновлення і втілення у правову реальність.

«Отже, з політичної позиції заслугою історичного погляду ми можемо назвати виступ проти віри у всемогутність і свавілля державної влади у сфері права і проти ілюзії історичної довільності» [3, с. 98]. У цій цитаті Ієринг підкреслює, що народний дух додає історичному виміру права логічності і розумності, адже у тенетах історії можна відшукати правові положення, що не відповідають правовій істині, тому мова іде саме про те, що є благом для нації, а не про будь-який норматив. Завдання держави це виявлення атрибутів правового буття у народному дусі, тим самим, держава є правовою, а не право - державним, що черговий раз піднімає онтологічне питання праворозуміння, а саме, що це складова буття людини, а держава є лише організаційною надбудовою.

Правовий субстанціоналізм Савіньї. «Савіньї показав вплив народної індивідуальності на право, а також те, як з часом слабшає глибина початкового зв'язку права 3 народом, який тим не менш ніколи не зникає, як кожен період, поряд з його своєрідністю і свободою, все ж різнобічно залежить від минулого і як саме завдяки цьому органічно розвивається право» [3, с. 76]. Народ є неповторним правотворцем. Те право, що створюють різні народи не одне і теж. Втім, як же ці позиції узгоджуються із онтологічним правороумінням? Допомогти тут може поняття субстанції як сутності, що може існувати сама по собі незалежно ні від чого. Народ у Савіньї виступає правовою субстанцією, у якій закладений загальний зміст і атрибути правового буття, а от модуси їх існування задає уже сила народного духу, що відповідає за оформлення правових змістів. Таким чином розгортання атрибутів правового буття є явище індивідуальне, при чому одиницею виступає окремий народ, в якому правове буття розкривається у певній самобутності. Саме звідси й отримує свою логіку принцип історизму, адже правове буття без його особливого розгортання у соціумі втрачає свою цінність і силу, а якщо це розгортання пов'язане із народною індивідуальністю, то цей зв'язок $\epsilon$, поки є народ, а витоки його знаходяться у минулому.

Онтологічна рівновага традицій $i$ новацій. Савіньї на прикладі римського права i народу демонструє наскільки важливим є поєднання традицій, що означають минуле та новацій, що втілюються у творчості теперішнього в праві: «Тим, що зробило Рим великим, був активний, живий, політичний сенс, яким цей народ був готовий завжди оновлювати форми свого державного устрою таким чином, щоб нове служило тільки для розвитку старого - це правильна симетрія між наполегливими і рушійними силами» [4, с. 143]. Яка може бути небезпека відірваності від старого? Це постійна мінливість, що може втратити стійкість, а тоді право втрачає свої субстанціональні основи. Зауважимо, що нове має служити для розвитку старого, а не навпаки. Погляд наче б то не дуже прогресивний, втім маємо пам'ятати, що старе це «відомість», а нове це «невідомість». Німецький дух може посприяти розробці Німецького цивільного уложення, а може і утвердженню расистських законів. У другому випадку старе служило для нового. Звісно, зовсім не обов'язково, щоб розвиток був такий деструктивний, результатом можуть бути і акти про права людини, втім з позиції онтологічної Савіньї цілком можна зрозуміти, адже ризик це не правове явище, і на нього покладатись - не є в дусі впорядкування.

Форми, що породжує національний дух підлягають розпаду в часі, а сам дух - ні. «Не можна заздалегідь передбачити, скільки $з$ давньогерманських інститутів можна буде відродити як в основному законі, так і в цивільному праві. Зрозуміло, не за буквою, а за духом, але споконвічний дух можна взнати тільки з давньої букви» [4, с. 186]. Саме тому Савіньї використовує поняття духу, а не, скажімо, звичаю, який важливий, але випробування історією може не витримати. Савіньї не є правовим ретроградом, він цілком свідомий того, що давня буква закону може не відродитись навіть не тому, що ії забули, а тому, що не відповідає духу епохи. Тому філософ обгрунтовує важливість збереження духу закону, щоб правосвідомість мала національне забарвлення, що здатне її максимально укріпити.

Історичне доведення правового буття. Савіньї формулює свого роду історичне доведення правового буття як невід’ємності існування: «Там, де ми вперше зустрічаємо доку-

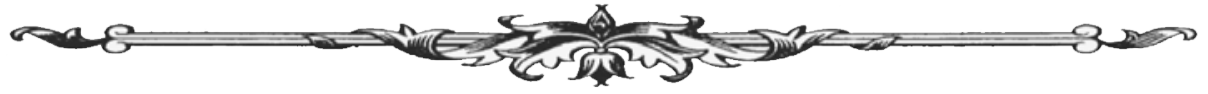


ментальну історію, цивільне право вже володіє певним характером, властивим народу так само, як його мова, звичаї, його устрій» [4, с. 130]. Тобто скрізь де має місце співбуття, там завжди присутнє право. Як тільки соціальна спільнота отримує свою організацію, як тільки між людьми виникають особливого складу зв'язки, одразу ж з'являється право не як продукт творчості, а як необхідність, що забезпечує народження, існування та збереження соціальної системи. Слушно сформулював П.І. Новгородцев: «Савіньї думає, що історичний процес управляється законом внутрішньої необхідності. Життя народу, як і окремих осіб ні на хвилину не знає абсолютного застою» [5, с. 83].

«Таким чином, право розвивається разом з народом, формується разом з ним i, нарешті, вмирає, як тільки народ втрачає свою своєрідність» [4, с. 133]. Народ - це дух права, а без духу тіло помирає. Справа в тому, що сприйняти правове буття, на думку Савіньї, може лише складана людська спільнота (адже проста, зокрема, сім'я здатна лише на простому рівні розкривати атрибути правового буття), що має вирізнятися індивідуальністю й автентичністю, що дає здатність щось генерувати від свого імені, а це - нація.

Савіньї обгрунтовує позицію про екзистенціальність права: «Право не існує саме для себе, його сутністю, навпаки, є життя самих людей, що розглядається з особливого боку» $[4$, c. 142]. Право не є річчю у собі, це складова буття та існує лише в антропологічному вимірі, тому розпізнати його може лише правосвідомість. Правове буття $є$ проявом правових атрибутів у співбутті

Савіньї демонструє історичний колапс «неісторичного» підходу: «Неісторична школа, навпаки, вважає, що право довільно породжується в будь-який момент особами, наділеними законодавчою владою, абсолютно незалежно від права минулого часу і лише відповідно до повного переконання, яке несе 3 собою теперішній момент» [6, с. 212]. У разі відсутності історичного принципу походження права воно стає позадосвідним, а його минуле має лише архівне значення. Зворотна сила права полягає не лише у застосуванні закону щодо минулих подій, а і щодо пошуку витоків.

3міст права. Савіньї доволі вдало формує алгоритм змісту права, а саме, «факт-загальне право-конкретне право»: «Судити про окреме праві можна лише шляхом встановлення відносин особливих фактів до загального правила, яке панує над окремими правами. Ми називаємо це правило Право як таке, або загальне право; деякі називають його правом в об'єктивному розумінні. Воно проявляється у видимій формі в законі, який є судженням вищої державної влади про правову норму» [7, с. 279]. Історичний метод підтверджує невід'ємність атрибуту ієрархії у праві, адже зіставляти факти ми маємо в першу чергу із загальними положеннями, інакше існує ризик правового казуїстичного хаосу, коли конкретні норми виходять за межі заданих атрибутами правового буття змістів. Концепція правового буття необхідна, тому що право це не просто сукупність відчужених регулятивів, це ще й їх ставлення до існуючої реальності. Право це завжди буття. Хтось вважає, що це буття природи людини, або буття космосу, або буття Бога, або держави відносно людей. Об'єднує ці погляди те, що право є невід'ємною складовою частиною нашого співіснування незалежно від того звідки ми його виводимо.

Індивідуальне та колективне у праві. Історична школа проводить чітку межу між індивідуальним і колективним у праві: «Його у жодному разі не можна розуміти так, ніби його творить воля окремих членів народу, тому що така воля окремих людей могла б випадково вибрати таке ж право, але більш імовірно, що вона вибрала б щось інше. Навпаки, те, що творить позитивне право, є народний дух, що сукупно живе і діє на всіх окремих людей; отже, у свідомості кожного індивіда це право стає одним і тим же правом не випадково, а неминуче» [7, с. 282]. Право і окремий, відірваний від співіснування індивід несумісні, тому воно походить зі співбуття людей, а наші внутрішні афекти - це питання психологічні. Більше того, співіснування виробляє стійкіші нормативи, ніж окрема сингулярність, тому кількісно на них завжди більше людей погодяться, оскільки мають більш вдали «спільний знаменник» взаємних зобов' язань. Савіньї складно збагнути як продукт колективності може бути зіставлений з індивідуальною творчістю в праві, і розуміє, що закономірності у цьому

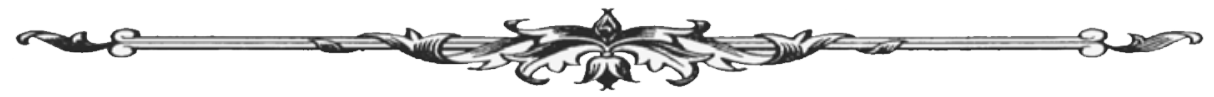


немає, а значить - лише випадковість. Як ми вже згадували, право не може собі дозволити випадковість як засіб регулювання, адже побудоване на стійких незмінних атрибутах.

Висновки. 1. Історична школа наголошує на обов'язковості часового виміру у праві, право у часі не просто є, воно змінюється, а отже, час є головним чинником його генезису.

2. Правове буття розкривається через розуміння, пізнання, засвоєння правового, а не через його творення. Право це той параметр, що уже заданий буттям. Правова діяльність людини і істинний зміст права цілком можуть і не пересікатись, адже правова істина може суб'єктом і не розкритись, або підмінити їі зміст.

3. Історична шкода декларує позицію, що правове буття розгортається не перспективно, а ретроспективно, воно уже розгорнуте, лиш потребує розумових вольових зусиль суб'єкта по збереженню його змісту.

4. Для історичної школи права істині витоки всього правового можуть бути лише у національних локаціях Нація дає правову матерію, без якої немає правового буття. Таким чином правова діяльність людини полягає не у створенні нових норм, а в узгодженні їх iз правилами народного духу.

5. Із аналізу поглядів Савіньї випливає генетично-правовий висновок: як тільки соціальна спільнота отримує свою організацію, як тільки між людьми виникають особливого складу зв'язки, одразу ж з'являється право не як продукт творчості, а як необхідність, що забезпечує народження, існування та збереження соціальної системи.

\section{Список використаних джерел:}

1. О. фон Гирке. Естественное право и немецкое право. Савиньи Ф.К., фон. Система современного римского права. Т. I / пер. с нем. Г. Жигулина ; под ред. О. Кутателадзе, В. Зубаря. Москва : Статут. 2011. 510 с.

2. О. фон Гирке. Историческая школа права и германисты. Савиньи Ф.К., фон. Система современного римского права. Т. I / пер. с нем. Г. Жигулина ; под ред. О. Кутателадзе, В. Зубаря. Москва : Статут. 2011. 510 с.

3. Рудольф фон Иеринг. Историческая школа юристов. Савиньи Ф.К., фон. Система современного римского права. Т. I / пер. с нем. Г. Жигулина ; под ред. О. Кутателадзе, В. Зубаря. Москва : Статут. 2011. 510 с.

4. Савиньи Ф.К.. фон. О призвании нашего времени к законодательству и юриспруденции. Савиньи Ф.К., фон. Система современного римского права. Т. I / пер. с нем. Г. Жигулина ; под ред. О. Кутателадзе, В. Зубаря. Москва : Статут. 2011.510 с.

5. Новгородцев П.И. Историческая школа юристов, ее происхождение и судьба: Опыт характеристики основ школы Савиньи в их последовательном развитии. Москва, 1896. 226 с.

6. Савиньи Ф.К. фон. О предназначении «Журнала по исторической юриспруденции. Савиньи Ф.К., фон. Система современного римского права. Т. I / пер. с нем. Г. Жигулина ; под ред. О. Кутателадзе, В. Зубаря. Москва : Статут. 2011. 510 с.

7. Савиньи Ф.К., фон. Система современного римского права. Т. I / пер. с нем. Г. Жигулина ; под ред. О. Кутателадзе, В. Зубаря. Москва : Статут. 2011.510 с.

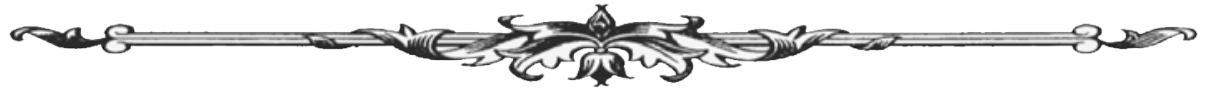

